\title{
Pengembangan Agribisnis Ikan Balita di UD Suhada, Kabupaten Cianjur
}

\author{
Agribusiness Development in Balita Fish \\ at UD Suhada, in Cianjur Regency
}

\author{
Andi Asrianto Iskandar ${ }^{1}$, Sapta Raharja ${ }^{2}$ dan Komar Sumantadinata ${ }^{3}$ \\ ${ }^{1}$ PT Bank Saudara Tbk \\ Jl. Pangkalan Raya No. 8 Warung Jambu, Bogor \\ ${ }^{2}$ Departemen Teknologi Industri Pertanian, Fakultas Teknologi Pertanian, Institut Pertanian Bogor \\ Jl. Kamper, Kampus IPB Darmaga, Bogor 16680 \\ ${ }^{3}$ Departemen Budidaya Perikanan, Fakultas Perikanan dan IImu Kelautan, Institut Pertanian Bogor \\ Jl. Agatis, Kampus IPB Darmaga, Bogor 16680
}

\begin{abstract}
ABSTRAK
Permintaan pasar dunia untuk produk perikanan meningkat bahkan seringkali tidak terpenuhi, maka diperlukan upaya mengatasi permasalahan dalam memenuhi permintaan produk perikanan. Jenis ikan air tawar dibudidayakan untuk ikan balita di UD Suhada adalah jenis nila dan ikan mas. Tujuan dari penelitian ini adalah untuk menguji kelayakan balita investasi agribisnis ikan di UD. Suhada, mengidentifikasi faktor-faktor internal dan eksternal yang mempengaruhi pengembangan agribisnis ikan balita di UD Suhada, merumuskan dan merekomendasikan strategi pembangunan alternatif yang tepat untuk diterapkan untuk ikan agribisnis balita di UD Suhada dalam pengembangan bisnis. Metode pengumpulan data menggunakan metode purposive sampling, yaitu dengan sengaja memilih contoh yang diteliti sebagai responden. Responden dipilih dari manajemen dan pekerja UD Suhada. Analisis keuangan pada $14 \%$ suku bunga dan 5 tahun masa proyek menghasilkan keputusan layak dengan Rp1.105.005.110 Net Present Value (NPV), 4,85 Benefit Cost (B/C Ratio), Internal Rate of Return (IRR) 38.95\%, 3 tahun dan 5 bulan Payback Period (PBP), dan Rp1.522.035.876 atau 32,725 kg Break Even Point (BEP). Kombinasi nilai Internal Factor Evaluation (IFE) nilai External Factor Evaluation (EFE) untuk 2,688 dan 2,651 dalam matriks Internal External (IE) menunjukkan bahwa posisi bisnis dalam V (lima) sel, pertumbuhan sel. Berdasarkan analisis Strenght, Weaknesses, Opportunities and Threats (SWOT) dan analisis Quantitative Strategic Planning Mantrix (QSPM) prioritas strategis untuk menciptakan berbagai macam produk, dengan tetap menjaga mutu ikan balita, memperluas jangkauan distribusi dan pemasaran, bekerjasama dengan para peneliti dalam mengembangkan mutu produk ikan balita menghadapi persaingan.
\end{abstract}

Kata kunci: ikan balita, kelayakan usaha, agribisnis, strategi pengembangan usaha

ABSTRACT

The world market demand for fishery products is increasing even frequently not fulfilled. It required an effort to overcome the problems in fulfilling the demand for fishery products. Types of freshwater fish cultivated for balita fish at UD Suhada is a type of tilapia and goldfish. The purpose of this study is to examine the feasibility of balita fish agribusiness investment in UD Suhada; identify the internal and external factors that influence the development of agribusiness balita fish at UD Suhada; formulate and recommend appropriate alternative development strategies to be applied to agribusiness balita fish at UD Suhada in business development. Methods of data collection using purposive sampling method, is by deliberately selecting the sample to be studied as a respondent. Respondents were selected from the management and the workers UD Suhada. Financial analysis at 14 percent of interest rate and 5 years of project lifetime resulted in feasible decision with Rp1,105,005,110 of NPV; 4.85 of net B/C Ratio; 38.95 percent of IRR, 3 years and 5 month of PBP; and Rp1,522,035,876 or $32.725 \mathrm{~kg}$ of BEP. The combination of value IFE EFE values for 2.688 and 2.651 in the IE matrix shows that the position of the business in V (five) cells, that cell growth. Based on the SWOT analysis and QSPM analysis the strategic priorities is to create a diverse variety of products while maintaining the quality of balita fish, extending the range of distribution and marketing, in collaboration with researchers in developing the quality of balta fish products to face competition.

Keywords: balita fish, business feasibility, agribusiness, business development strategy

\footnotetext{
*) Korespondensi:

Jl. Pangkalan Raya No. 8 Warung Jambu, Bogor; e-mail: andi250109@gmail.com
} 


\section{PENDAHULUAN}

Indonesia merupakan negara kaya sumber daya alam dan potensi pertanian yang terkandung didalamnya, diantaranya pada sub sektor perikanan. Salah satu usaha budi daya perikanan yang memiliki potensi dan dapat memberikan kontribusi cukup nyata bagi kehidupan masyarakat Indonesia adalah usaha budi daya perikanan ikan air tawar. Untuk mengupayakan usaha sektor budi daya perikanan air tawar ini dapat berfungsi dengan baik yang mampu menghasilkan produk berdaya saing tinggi, maka perlu dikelola secara profesional untuk menambah nilai komersialnya. Dengan pendekatan sistem agribisnis perikanan, tersebut dapat diakomodir dalam membangun subsektor perikanan, dalam hal ini perikanan budi daya. Menurut Saragih (2010) pembangunan subsektor perikanan dengan pendekatan sistem agribisnis yang dimaksud adalah membangun dan mengembangkan subsistem industri hulu perikanan (perbenihan, industri peralatan penangkapan ikan, industri pakan ikan), subsistem budi daya atau penangkapan ikan dan penanganan pasca penangkapan, subsistem pengolahan hasil perikanan dan perdagangan, subsistem jasa penunjang (terutama kegiatan penelitian dan pengembangan) secara terintegrasi dalam suatu sistem, baik sistem nilai maupun pengelolaannya.

Agribsisnis ikan balita merupakan salah satu peluang usaha di sektor agribisnis ikan air tawar yang berkembang pesat sampai saat ini. Ikan balita merupakan jenis ikan air tawar, para kalangan praktisi perikanan menyatakan bahwa ikan balita tidak hanya untuk sekedar menggambarkan bahwa ikan tersebut masih berukuran kecil, lebih spesifik lagi menyangkut dimensi atau ukuran panjang tubuh. Istilah balita diambil dari akronim di bawah lima sampai tiga sentimeter atau kalau dinotasikan secara singkat: ikan berukuran di bawah $3 \mathrm{~cm}$ sampai $5 \mathrm{~cm}$. Namun dalam kenyataannya, ikan balita banyak menggunakan ikan dengan ukuran lebih besar, yaitu 5-8 $\mathrm{cm}$. Jenis ikan air tawar yang dibudidayakan untuk ikan balita adalah jenis ikan nila, ikan mas, ikan nilem, ikan mujair, ikan lele dan ikan gurame (Amri dan Khairuman, 2007).

Terbatasnya bentuk olahan ikan merupakan salah satu penyebab rendahnya tingkat konsumsi ikan penduduk Indonesia. Untuk meningkatkan konsumsi ikan, perlu ditempuh penganekaragaman (diversifikasi) bentuk olahan ikan, terutama menuju pada produk-produk yang biasa dikonsumsi masyarakat, sehingga peluang produk untuk diterima lebih besar (Nainggolan et al. 2010). Produk ikan balita yang dapat dikonsumsi masyarakat adalah produk ikan balita goreng. Selain pemanfaatan ikan balita sebagai kebutuhan konsumsi konsumen yang menyukai menu ikan balita goreng, tetapi juga untuk memenuhi permintaan pasar alternatif lainnya. Peluang pasar alternatif sangat potensial tersebut adalah pemanfaatan ikan balita sebagai pakan ikan hias tertentu dan untuk memenuhi permintaan para pendeder ikan yang membesarkan ikan balita menjadi ikan remaja dan dewasa (konsumsi berukuran besar).

Selain keuntungan yang berlipat, bisnis ikan balita juga minim risiko. Ikan balita dapat dipanen lebih cepat, biaya produksi pun bisa ditekan. Biaya operasional yang terkonsentrasi untuk pakan berkisar $80 \%$ atau lebih bisa ditekan menjadi nol (Serial, 2007).

Kecamatan Karangtengah dengan luas wilayah $4.618 \mathrm{Ha}$, merupakan salah satu kecamatan dari 32 kecamatan yang terdapat di Kabupaten Cianjur, Jawa Barat. Kecamatan Karangtengah terletak pada ketinggian 255 meter dari permukaan laut (mdpl), memiliki curah hujan cukup banyak setiap tahunnya $(4.680 \mathrm{~mm})$, sehingga secara geografis Kecamatan Karangtengah merupakan salah satu kecamatan di Kabupaten Cianjur yang berpotensi dalam pengembangan usaha budi daya ikan air tawar serta produk olahannya. Berdasarkan data dari Dinas Peternakan, Perikanan dan Kelautan Kabupaten Cianjur, di Kecamatan Karangtengah terdapat 252 Unit Pembenihan Rakyat (UPR) dengan luas areal 122,7 ha menghasilkan benih ikan mas, ikan nila dan ikan lele. Benih ikan mas merupakan jenis benih ikan yang paling banyak dihasilkan dari UPR tersebut dibandingkan dengan benih jenis ikan lainnya (Tabel 1). Benih ikan mas merupakan salah satu jenis ikan sebagai bahan baku ikan balita.

Tabel 1. Produksi benih ikan dari UPR Kecamatan Karangtengah, Kabupaten Cianjur Tahun 2011-2012

\begin{tabular}{cccc} 
& & \multicolumn{2}{c}{ Satuan : 1.000/eko } \\
No. & Jenis & \multicolumn{2}{c}{ Tahun } \\
\cline { 3 - 4 } & Ikan & \multicolumn{1}{c}{$\mathbf{2 0 1 1}$} & \multicolumn{1}{c}{$\mathbf{2 0 1 2}$} \\
\hline 1 & Mas & $1,256,067.37$ & $1,414,147.54$ \\
2 & Nila & $1,140,480.50$ & $1,271,375.76$ \\
3 & Lele & $6,019.05$ & $16,246.24$ \\
\hline
\end{tabular}

Sumber: Dinas Peternakan, Perikanan dan Kelautan Kabupaten Cianjur, 2012.

Tujuan penelitian ini (1) mengkaji kelayakan investasi agribisnis ikan balita di UD Suhada dilihat dari aspek non finansial dan aspek finansial, (2) mengidentifikasi faktor-faktor internal dan eksternal yang berpengaruh terhadap pengembangan agribisnis ikan balita di UD Suhada dan (3) merumuskan dan merekomendasikan alternatif strategi pengembangan yang tepat untuk diterapkan bagi agribisnis ikan balita di UD Suhada dalam pengembangan usahanya.

\section{METODOLOGI}

Lokasi penelitian adalah UD Suhada Kecamatan Karang Tengah, Kabupaten Cianjur, Jawa Barat pada tahun 2012. Penelitian ini menggunakan metode pengolahan data secara kualitatif dan kuantitatif. 
1. Analisis kualitatif

Dalam studi kelayakan, perlu diperhatikan aspek-aspek yang secara bersama-sama menentukan bagaimana keuntungan yang diperoleh dari suatu penanaman investasi tertentu. Menurut Latifah, Suryani dan Hardjomidjojo (2009), aspek-aspek analisis kelayakan proyek terdiri dari aspek pasar, aspek teknis, aspek manajemen, dan aspek sosial.

2. Analisis kuantitatif

Menurut Husnan dan Suwarsono (2000), pada umumnya ada lima metode yang biasa dipertimbangkan untuk dipakai dalam penilaian investasi. Metode tersebut diantaranya metode Average Rate Return, Payback Periode (PBP), Present Value, Internal Rate Return (IRR), serta Profitability Indeks (PI). Selain itu, menurut Latifah et al (2009) menyebutkan bahwa dana yang diinvestasikan itu layak atau tidak akan diukur melalui kriteria investasi Net Present Value (NPV), Gross Benefit Cost Ratio dan Internal Rate Return (IRR).

3. Proses Perumusan Strategi

Langkah-langkah yang dilakukan dalam proses perumusan strategi ini adalah:

a. Mengumpulkan data informasi yang berhubungan dengan obyek penelitian dalam bentuk pertanyaan atau hasil wawancara, data berbentuk gambar-gambar, maupun tabel-tabel untuk mempermudah dalam menganalisis lebih lanjut. Alat analisis yang digunakan adalah matriks IFE (Internal Factor Evaluation) dan matriks EFE (External Factor Evaluation).

b. Mengkaji situasi perusahaan secara internal dan eksternal dengan mengidentifikasikan kekuatan dan kelemahan dengan peluang dan ancaman perusahaan, kemudian menghubungkannya untuk mengetahui posisi perusahaan saat ini. Alat analisis yang digunakan adalah matriks IE (InternalExternal) dan matriks SWOT (Strengths, Weaknesses, Oppotunities, and Threats).

c. Menentukan alternatif dan prioritas strategi yang tepat bagi perusahaan. Alat analisis yang digunakan pada tahap ini adalah Quantitative Strategic Planning Matrix (QSPM).

\section{HASIL DAN PEMBAHASAN}

Pengolahan ikan balita merupakan suatu solusi bagi para petani minapadi yang semula terkendala pemasaran, menjadi suatu peluang usaha berprospek sangat baik, sehingga diperlukan suatu unit perusahaan yang dapat menjadi wadah penyaluran produk-produk ikan hasil minapadi ini sampai kepada produsen. Hal ini sesuai dengan visi dan misi UD Suhada,yang merupakan visi UD Suhada adalah "Meningkatkan Mutu daya kerja masyarakat dan menciptakan manusia produktif", sedangkan misi UD Suhada adalah "Selalu memberikan terbaik dan bermanfaat".

\section{Analisis Kualitatif}

\section{Aspek pasar}

a. Potensi dan Pangsa pasar.

Untuk saat ini wilayah pemasaran ikan balita dan produk olahannya meliputi : (1) Ikan balita segar dipasarkan di wilayah Cianjur; (2) Ikan balita segar-mati-kemasan dipasarkan hampir seluruh supermarket di wilayah Jabodetabek, kecuali Giant supermarket dan Yogya Supermarket serta catering di wilayah Jabodetabek; (3) Ikan balita goreng dalam kemasan dipasarkan di supermarket, restoran, tempat wisata dan toko cinderamata wilayah Jabodetabek.

b. Produk dan Harga Ikan Balita

UD Suhada memiliki bahan baku ikan mas dan ikan nila dengan menawarkan berbagai macam produk dengan harga yang bervariasi, seperti dimuat pada Tabel 2 .

Tabel 2. Jenis dan harga produk ikan balita di UD Suhada

\begin{tabular}{clcc}
\hline No. & $\begin{array}{c}\text { Produk Ikan } \\
\text { Balita }\end{array}$ & Harga (Rp) & Satuan \\
\hline 1 & Segar & 25.000 & $\mathrm{~kg}$ \\
2 & Segar-Mati- & $43.000 \mathrm{~s} / \mathrm{d}$ & $\mathrm{kg}$ \\
& Kemasan & 45.000 & \\
3 & Goreng- & $17.000 \mathrm{~s} / \mathrm{d}$ & $100 \mathrm{~g}$ \\
& Kemasan & 20.000 & \\
\hline
\end{tabular}

c. Saluran Distribusi/Pemasaran

Distribusi pemasaran dengan cara membawa pesanan ikan balita ke beberapa tempat yang telah memesan di wilayah Jawa Barat dan Jabodetabek. Dengan sistem pembayaran berbeda-beda disetiap tempat, sebagian membayar tunai adapun yang membayar $10 \%$ sebagai tanda jadi dan sisanya dibayar lagi setelah pengiriman ikan berikutnya.

d. Strategi Perusahaan/Promosi

Dalam hal promosi, perusahaan ini telah mencapai ke tingkat nasional, dengan mengikuti pameran-pameran yang dilaksanakan pemerintah, baik pemerintah daerah, provinsi, bahkan sampai pemerintah pusat (dalam hal ini Kementerian Kelautan dan Perikanan). Beberapa pameran telah diikuti UD. Suhada sehingga secara tidak langsung mempromosikan produk ikan balita. Salah satu promosi produk ikan balita UD Suhada juga dengan mempromosikan lewat internet dan jejaring sosial. Dalam tahun 2012 UD Suhada telah membuka situs/blog produk ikan balita dengan nama web www.ikanmungil.com dan alamat email udsd_ikanmasbalita@yahoo.co.id. 
e. Pesaing/Persaingan Perusahaan

Menurut Kusumawardani et al (2012), persaingan pasar perlu menggunakan sumber daya secara efisien artinya seluruh sumbersumber daya yang tersedia sepenuhnya digunakan. Di wilayah Cianjur telah terdapat beberapa pengusaha yang memasarkan dan mengolah ikan balita, salah satu diantaranya adalah Pringgondani, adalah salah satu perusahaan yang mempunyai permodalan dengan jumlah lebih besar dibandingkan UD Suhada. Akan tetapi UD Suhada tidak menjadikan hal ini masalah dalam memasarkan produknya, karena masing-masing memiliki keunggulan produk dan jalur distribusi pemasaran yang berbeda dengan para pesaingnya.

f. Rencana/Proyeksi Penjualan

Pasokan ikan sebagai bahan baku, terutama berasal dari minapadi terbesar berada di empat wilayah, yaitu kecamatan Karangtengah, Sukaluyu, Cikalong dan Warungkondang. Luas areal persawahan mencapai $4.628 \mathrm{Ha}$ dengan potensi produksi ikan hasil minapadi $4.357,5$ ton/tahun atau 363,12 ton/bulan. Namun yang dimanfaatkan sebagai bahan baku pengolahan ikan balita baru sekitar 9-10 ton/bulan atau 2,5\% dari hasil minapadi. Target atau proyeksi penjualan UD Suahada dalam pengolahan ikan balita adalah menuju ke hasil optimal dalam beberapa tahun ke depan, dengan jumlah 15 ton/bulan.

\section{Aspek Teknis}

a. Lokasi dan Skala Produksi

Lokasi perusahaan yang didirikan UD. Suhada memiliki luas bangunan kolam $420 \mathrm{~m}^{2}$ dan luas tempat pengolahan $200 \mathrm{~m}^{2}$. Luas tempat penampungan dan pengolahan tersebut masih memerlukan perluasan, agar dapat memberikan hasil optimal. Untuk saat ini penyerapan pasar terhadap produk ikan balita hampir tak terbatas, artinya berapapun jumlah ikan balita yang diproduksi UD Suhada diserap oleh pasar, namun dengan keterbatasan tempat penampungan hanya mampu menampung $300-400 \mathrm{~kg} / \mathrm{hari}$.

b. Investasi dan Peralatan Proses Produksi

Sarana dan prasarana yang dimiliki UD Suhada untuk saat ini masih memadai untuk skala awal produksi. Biaya investasi yang dikeluarkan UD Suhada dalam usaha ikan balita bernilai Rp1.161.772.000 dalam beberapa periode. Biaya investasi terdiri dari dua periode, yaitu tahun 2008 dan 2010, tahun 2008 biaya investasi dikeluarkan untuk usaha ikan balita segar dalam kemasan dan pada awal tahun 2010 dikeluarkan untuk usaha pengolahan ikan balita goreng dalam kemasan.

c. Proses dan Biaya Produksi

Proses produksi ikan balita di UD Suhada cukup bervariasi, karena memilki dua bagian, yaitu bagian produk ikan balita segar dalam kemasan, serta produk ikan balita goreng dalam kemasan.

1) Proses pengemasan ikan balita segar

Benih ikan mas dan ikan nila sebesar ibu jari (ukuran 3-5 cm) diambil dari karamba (tempat pembenihan ikan) hasil minapadi di wilayah sekitar. Benih ikan tersebut dikumpulkan ke kolam sementara agar bertahan selama beberapa hari dan selanjutnya dilakukan pengelompokkan ukuran untuk memisahkan ukuran ikan, ukuran antara 3-5 $\mathrm{cm}$ dipisahkan dengan ukuran di atas $5 \mathrm{~cm}$. Kemudian benih ikan dibersihkan setelah itu ditimbang selanjutnya dimasukkan kedalam kemasan (tray) yang dilapisi tissue dan daun pisang. Rendemen konversi massa dari bahan baku ikan balita sampai menjadi ikan balita segar dalam kemasan adalah 10\% untuk ikan mas dan $15 \%$ untuk ikan nila.

2) Proses pembuatan dan pengemasan ikan balita goreng

Ikan balita yang akan dijadikan balita goreng dipilih dari jenis ikan nila atau ikan mas yang kondisinya masih segar. Untuk bahan baku dari UD Suhada masih dalam keadaan hidup dan masih segar. Selanjutnya dilakukan pengelompokan ukuran agar sesuai ukuran yang ditetapkan perusahaan (3-5 cm). Tahap berikutnya membersihkan bagian kotoran ikan. Ikan yang telah dibersihkan kemudian ditaruh dalam wadah khusus bersih untuk kemudian diberi bumbu. Bumbu ini merupakan ciri khas produk UD Suhada. Agar bumbu terasa sedap dan meresap sampai ke dalam daging ikan, maka ikan perlu direndam beberapa saat dalam larutan bumbu. Kemudian proses penggorengan dengan panas api yang sedang agar kematangan ikan goreng balita ini merata. Ikan balita yang telah digoreng, didiamkan/didinginkan terlebih dahulu sebelum ditimbang sesuai ukuran (rataan ukuran $100 \mathrm{~g} /$ bungkus). Proses terakhir adalah pengemasan dengan memasukkan ikan balita goreng kedalam kemasan (tray). Rendemen konversi massa dari bahan baku ikan balita sampai menjadi ikan balita goreng dalam kemasan adalah $70 \%$ untuk ikan mas dan ikan nila.

3) Biaya Produksi

Biaya tetap yang dikeluarkan usaha ikan balita di UD Suhada selama 5 tahun periode proyek berjalan bernilai berbedabeda setiap tahunnya, disebabkan adanya reinvestasi pada tahun 2010. Akan tetapi, secara keseluruhan nilai biaya operasional dalam periode satu tahun bernilai Rp2.694.101.150 (pada tahun 2010).

\section{Aspek Manajemen}

UD Suhada mempekerjakan tenaga kerja yang sebagian besar adalah masyarakat sekitar 
tempat usaha. Jumlah pegawai saat ini adalah 78 orang, yang terdiri dari 32 wanita dan 46 pria.

UD Suhada memberikan uang lembur bagi para tenaga pembersih dan pengemasan ikan balita segar dengan upah Rp5.000/jam, dengan waktu normal kerja untuk pekerja pria shift I (jam 13.30-16.30) dan shift II (jam 20.00-24.00) setelah melewati waktu shift II, maka upah lembur diberlakukan. Untuk wanita shift I (jam 08.0012.00), shift II (jam 14.00-16.30) dan shift III (jam 19.00-21.00), setelah melewati waktu shift III, maka upah lembur diberlakukan.

\section{Aspek Sosial}

Menurut Septiara, el al. (2012). Tingkat pendidikan merupakan salah satu faktor yang mempengaruhi kemampuan berfikir dan kemampuan untuk menyerap informasi dan inovasiinovasi baru. UD Suhada merekrut tenaga kerja penduduk sekitar yang mempunyai tenaga kompeten di bidang pengolahan ikan balita agar turut berpartisipasi menjalankan usaha tersebut. Hal ini dapat meningkatkan pendapatan dan kesejahteraan masyarakat Cianjur pada umumnya dan khususnya warga Kecamatan Karangtengah secara langsung dalam proses pengolahan ikan balita.

Pengolahan ikan balita merupakan suatu solusi bagi para petani minapadi yang semula terkendala pemasaran, menjadi suatu peluang usaha berprospek sangat baik. Kegiatan minapadi itu sendiri, menurut pengalaman para petani sekitar dapat meningkatkan produktifitas padi. Hal ini dimungkinkan adanya kotoran ikan yang dapat menyuburkan tanah, sedangkan hasil panen ikan merupakan pasokan bahan baku utama pada proses pengolahan.

\section{Analisis Kuantitatif}

Nilai kriteria kelayakan finansial usaha pengolahan ikan balita di UD Suhada sebagai berikut: 1. NPV

Berdasarkan perhitungan dengan tingkat suku bunga 14\% diperoleh nilai NPV Rp1.105.005. 110. Hal ini menunjukkan bahwa keuntungan usaha pengolahan ikan balita di UD Suhada selama 5 tahun umur investasi mendatangkan keuntungan 1,9 milyar rupiah. Akumulasi nilai NPV positif mengindikasikan bahwa usaha pengolahan ikan balita di UD Suhada menguntungkan dan layak dikelola.

2. Net $\mathrm{B} / \mathrm{C}$

Berdasarkan analisis perhitungan Net B/C Ratio diperoleh nilai Net B/C Ratio 4,85. Nilai Net B/C lebih besar dari satu menunjukkan bahwa usaha pengolahan ikan balita di UD Suhada layak dilaksanakan bila dilihat baik dari dampak sosial yang ditimbulkannya maupun dari segi finansialnya.
3. IRR

Nilai IRR usaha pengolahan ikan balita di UD. Suhada dari perhitungan NPV1; DF 14\% dan nilai NPV2; DF 20\% diperoleh nilai IRR 38,95\% dimana nilai ini lebih besar dari suku bunga bank komersial yang berlaku saat melakukan kajian, yaitu 14\%. IRR lebih besar dari bunga bank komersial mengindikasikan bahwa usaha pengolahan ikan balita di UD Suhada layak dilaksanakan.

4. PBP

Berdasarkan analisis perhitungan, PBP usaha pengolahan ikan balita di UD Suhada adalah 3,58 tahun. Dengan biaya investasi Rp1.161. 772.000 dan umur ekonomis usaha pengolahan ikan balita di UD Suhada selama 5 tahun, maka proyek ini dapat dikembalikan melalui arus kas selama 3,58 tahun. Nilai 3,58 tersebut lebih pendek dari jangka waktu umur ekonomis proyek investas. Hal ini mengindikasikan bahwa usaha pengolahan ikan balita di UD Suhada layak dikembangkan.

5. BEP

Berdasarkan analisis perhitungan BEP diketahui bahwa titik impas untuk usaha pengolahan ikan balita di UD Suhada pada penjualan senilai Rp.1.522.035.876 atau dapat juga dikatakan bahwa diperlukan penjualan 32.725 $\mathrm{kg}$ ikan balita segar untuk mendapatkan kondisi seimbang antara biaya dengan keuntungan.

\section{Perumusan Strategi}

\section{Analisis Matriks IFE}

Faktor yang dianalisis dalam matriks ini adalah faktor-faktor strategis internal perusahaan. Faktor-faktor strategik ini merupakan faktor-faktor yang menjadi kekuatan dan kelemahan unit usaha. Hasil identifikasi kekuatan dan kelemahan dimasukkan sebagai faktor-faktor strategik internal yang diberi bobot dan rating, sehingga diperoleh hasil identifikasi (Tabel 3).

\section{Analisis Matriks EFE}

Faktor yang dianalisis dengan matriks EFE adalah faktor-faktor strategik eksternal perusahaan. Faktor-faktor stretegik ini merupakan faktorfaktor yang menjadi ancaman dan peluang unit usaha. Hasil identifikasi peluang dan ancaman dimasukkan sebagai faktor-faktor strategik eksternal, yang diberi bobot dan rating, sehingga diperoleh hasil identifikasi (Tabel 4).

\section{Analisis Matriks IE}

Penentuan posisi strategi pada matriks IE didasarkan pada hasil total nilai IFE yang diberi bobot pada sumbu $x$ dan total nilai EFE pada sumbu y (David 2004). Nilai IFE yang diperoleh dari usaha ikan balita di UD Suhada 2.651 dan nilai EFE 2.688 (Gambar 1). 
Tabel 3. Faktor strategik internal usaha ikan balita UD Suhada

\begin{tabular}{clccc}
\hline No. & \multicolumn{1}{c}{ Faktor Internal } & $\begin{array}{c}\text { Bobot } \\
(\mathbf{a})\end{array}$ & $\begin{array}{c}\text { Rating } \\
\text { (b) }\end{array}$ & $\begin{array}{c}\text { Nilai } \\
(\mathbf{a x b})\end{array}$ \\
\hline Kekuatan: & & & \\
1 & Mutu benih ikan lebih baik & 0,069 & 3,333 & 0,231 \\
2 & Penanganan pasca panen cepat & 0,072 & 3,667 & 0,265 \\
3 & Kebutuhan tenaga kerja mudah & 0,058 & 3,667 & 0,214 \\
4 & Promosi & 0,051 & 4,000 & 0,206 \\
5 & Memiliki jaringan pemasok bahan baku & 0,074 & 3,667 & 0,270 \\
6 & Komunikasi dalam pekerjaan & 0,068 & 3,333 & 0,227 \\
7 & Lokasi usaha strategik & 0,071 & 3,333 & 0,236 \\
8 & Saluran distribusi pemasaran & 0,067 & 3,333 & 0,222 \\
Kelemahan: & & & \\
1 & Manajemen kontrol mutu & 0,060 & 1,667 & 0,100 \\
2 & Variasi produk & 0,053 & 1,667 & 0,089 \\
3 & Pencatatan data keuangan & 0,060 & 1,333 & 0,081 \\
4 & Kekurangan modal & 0,063 & 1,667 & 0,104 \\
5 & Keadaan SDM & 0,058 & 1,333 & 0,078 \\
6 & Lahan produksi & 0,058 & 2,000 & 0,115 \\
7 & Hasil produksi belum optimal & 0,055 & 2,000 & 0,110 \\
8 & Penggunaan teknologi & 0,063 & 1,667 & 0,104 \\
\hline & Jumlah & $\mathbf{1 , 0 0 0}$ & & $\mathbf{2 , 6 5 1}$ \\
\hline & & & & \\
\hline
\end{tabular}

Tabel 4. Faktor strategik eksternal usaha ikan balita UD Suhada

\begin{tabular}{rlrrr}
\hline No. & \multicolumn{1}{c}{ Faktor Eksternal } & $\begin{array}{c}\text { Bobot } \\
\mathbf{( a )}\end{array}$ & $\begin{array}{c}\text { Rating } \\
\mathbf{( b )}\end{array}$ & $\begin{array}{c}\text { Nilai } \\
\mathbf{( a x b )}\end{array}$ \\
\hline Peluang: & & & \\
1 & Sumber daya alam & 0,094 & 3,333 & 0,313 \\
2 & Kemajuan teknologi informasi & 0,080 & 3,667 & 0,294 \\
3 & Kebijakan pemerintah & 0,092 & 3,667 & 0,339 \\
4 & Potensi variasi produk & 0,077 & 4,000 & 0,309 \\
5 & Peningkatan permintaan ikan balita & 0,108 & 3,333 & 0,359 \\
6 & Kondisi pasar terbuka & 0,094 & 3,333 & 0,313 \\
Ancaman: & & & \\
1 & Kenaikan harga BBM & 0,073 & 2,000 & 0,145 \\
2 & Fluktuasi harga benih ikan & 0,114 & 2,000 & 0,227 \\
3 & Produksi sejenis dari wilayah lain & 0,092 & 1,667 & 0,154 \\
4 & Isu penyakit ikan & 0,077 & 1,333 & 0,103 \\
5 & Perubahan kultur masyarakat & 0,098 & 1,333 & 0,131 \\
\hline & Jumlah & $\mathbf{1 , 0 0 0}$ & & $\mathbf{2 , 6 8 8}$ \\
\hline
\end{tabular}

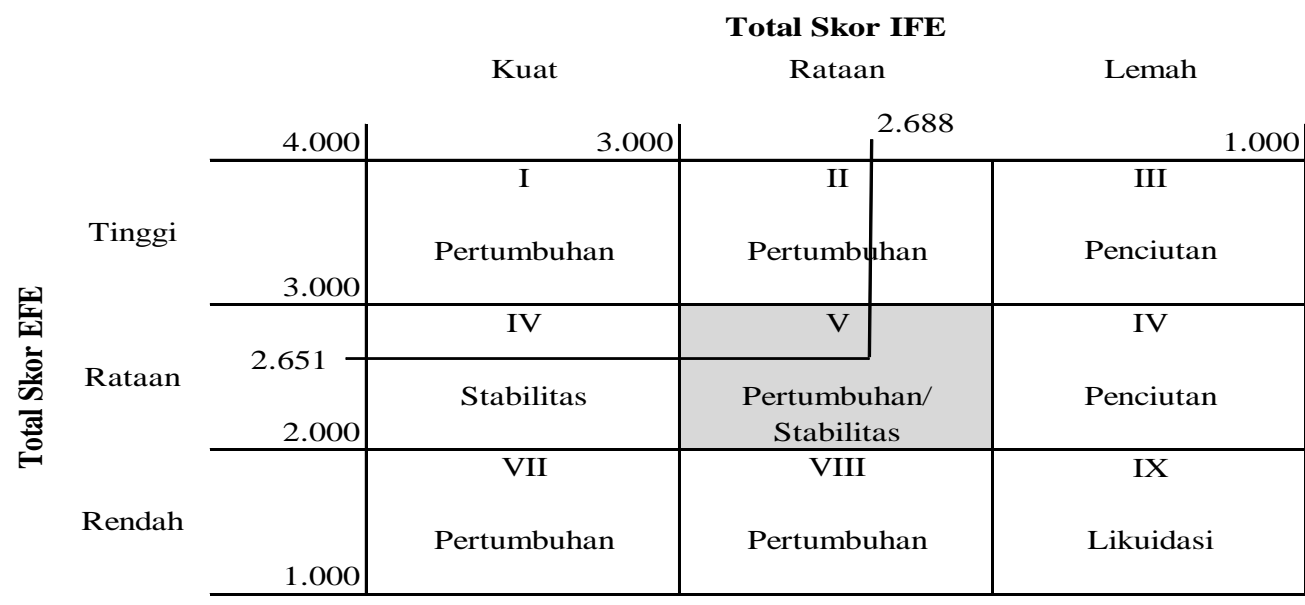

Gambar 1. Matriks IE UD Suhada 
Dari hasil evaluasi dan analisis yang telah dilakukan, selanjutnya dilakukan analisis IE yang menghasilkan matriks IE untuk mengetahui posisi perusahaan dalam pemilihan alternatif strategik. Dalam hal ini, pemetaan posisi usaha sangat penting bagi pemilihan alternatif strategi untuk menghadapi persaingan dan perubahan yang terjadi dalam usaha ikan balita di UD Suhada. Total nilai pada matriks internal 2,688, maka usaha ikan balita di UD Suhada tergolong sedang atau rataan. Total nilai pada matriks eksternal 2,651, memperlihatkan respon yang diberikan oleh usaha ikan balita UD Suhada kepada lingkungan eksternal tergolong sedang atau rataan.

Perpaduan dari kedua nilai tersebut menunjukkan bahwa strategi utama bagi pengembangan usaha terletak pada sel V (lima). Sel V dikelompokkan dalam strategi pertumbuhan melalui konsentrasi integrasi vertikal, dengan cara backward integration (mengambil alih fungsi supplier) atau dengan cara forward integration (mengambil alih fungsi distributor). Untuk meningkatkan kekuatan bisnisnya, harus dilaksanakan upaya meminimalkan biaya dan operasional yang tidak efisien untuk mengontrol mutu dan distribusi produk. Integrasi vertikal dapat dicapai baik melalui sumber daya internal maupun eksternal. Usaha ikan balita di UD Suhada dapat mengembangkan usahanya dengan cara perluasan usaha, mengembangkan produk yang bervariasi, menambah mutu produk dengan menggunakan teknologi lebih modern, memperluas wilayah pasar dan memperluas segmentasi pasar.

\section{Matriks SWOT}

Penyusunan alternatif strategi pengembangan usaha ikan balita di UD Suhada dapat dirumuskan berdasarkan analisis matriks SWOT. Penyusunan formulasi strategi dilakukan dengan mengkombinasikan berbagai faktor yang telah diidentifikasi dan dikelompokkan. Hasil formulasi dikelompokkan menjadi empat kelompok formulasi strategi yang terdiri dari strategi Kekuatan-Peluang (S-O), strategi KekuatanAncaman (S-T), strategi Kelemahan-Peluang (WO) dan stretegi Kelemahan-Ancaman (W-T).

\begin{tabular}{|c|c|c|}
\hline Faktor Eksternal & $\begin{array}{l}\text { Kekuatan (S) } \\
\text { 1. Mutu benih ikan lebih baik } \\
\text { 2. Penanganan pasca panen yang } \\
\text { cepat } \\
\text { 3. Kebutuhan tenaga kerja yang } \\
\text { mudah } \\
\text { 4. Promosi } \\
\text { 5. Memiliki jaringan pemasok } \\
\text { bahan baku } \\
\text { 6. Komunikasi dalam pekerjaan } \\
\text { 7. Lokasi usaha strategik } \\
\text { 8. Saluran distribusi pemasaran }\end{array}$ & \begin{tabular}{ll} 
& \multicolumn{1}{c}{ Kelemahan (W) } \\
1. & Manajemen kontrol mutu \\
2. & Variasi produk \\
3. & Pencatatan data keuangan \\
4. & Kekurangan modal \\
5. & Keadaan SDM \\
6. & Lahan produksi \\
7. & Hasil produksi belum optimal \\
8. & Penggunaan teknologi
\end{tabular} \\
\hline $\begin{array}{l}\quad \text { Peluang (O) } \\
\text { 1. Sumber daya alam } \\
\text { 2. Kemajuan teknologi } \\
\text { informasi } \\
\text { 3. Kebijakan pemerintah } \\
\text { 4. Potensi variasi produk } \\
\text { 5. Peningkatan permintaan } \\
\text { ikan balita } \\
\text { 6. Kondisi pasar terbuka }\end{array}$ & $\begin{array}{l}\text { Strategi SO (agresif) } \\
\text { 1. Meningkatkan produksi dan } \\
\text { produktivitas usaha ikan balita } \\
\text { dalam memanfaatkan permin- } \\
\text { taan ikan balita yang semakin } \\
\text { meningkat (S2,S5,S7, } \\
\text { O1,O2,O3,O4,O5,O6) } \\
\text { 2. Menciptakan variasi produk yang } \\
\text { beragam dengan tetap } \\
\text { mempertahankan mutu ikan } \\
\text { balita (S1,S2,S7,O1,O4,O5,O6) } \\
\text { 3. Memanfaatkan teknologi } \\
\text { informasi dalam mempromosi- } \\
\text { kan produk ikan balita } \\
\text { (S4,S8,O1,O2,O3,O4,O5,O6) }\end{array}$ & $\begin{array}{l}\text { Strategi WO (diversifikasi) } \\
\text { 1. Memanfaatkan kemajuan } \\
\text { teknologi informasi dalam } \\
\text { menggunakan lahan terbatas } \\
\text { (W6,W8,O2,O3,O6) } \\
\text { 2. Meningkatkan kemampuan } \\
\text { SDM dengan memanfaatkan } \\
\text { dukungan pemerintah dan mitra } \\
\text { usaha (W1,W4,W5,O3,O6) } \\
\text { 3. Memanfaatkan teknologi } \\
\text { informasi dalam mencari } \\
\text { informasi tentang peralatan } \\
\text { maupun perlengkapan usaha } \\
\text { lebih modern (W7,W8,O2,O6) }\end{array}$ \\
\hline $\begin{array}{l}\quad \text { Ancaman (T) } \\
\text { 1. Kenaikan harga BBM } \\
\text { 2. Fluktuasi harga benih ikan } \\
\text { 3. Produksi sejenis dari } \\
\text { wilayah lain } \\
\text { 4. Isu penyakit ikan } \\
\text { 5. Perubahan kultur } \\
\text { masyarakat }\end{array}$ & $\begin{array}{l}\text { Strategi ST (diferensiasi) } \\
\text { 1. Pengembangan segmentasi } \\
\text { usaha dalam menghadapi } \\
\text { fluktuasi harga (S5,S8,T1,T2) } \\
\text { 2. Memperluas jangkauan distribusi } \\
\text { dan pemasaran }(\mathrm{S} 5, \mathrm{~S} 8, \mathrm{~T} 2, \mathrm{~T} 3) \\
\text { 3. Bekerjasama dengan pihak } \\
\text { peneliti dalam mengembangkan } \\
\text { mutu produk ikan balita guna } \\
\text { menghadapi persaingan usaha } \\
\text { (S1,T1,T2,T3) }\end{array}$ & $\begin{array}{l}\text { Strategi WT (defensif) } \\
\text { 1. Mengoptimalkan sumber daya } \\
\text { yang dimiliki dalam mengatasi } \\
\text { persaingan usaha } \\
\text { (W5,W6,W7,T2,T3) } \\
\text { 2. Mempertahankan mutu produk } \\
\text { dalam menghadapi persaingan } \\
\text { usaha (W1,W2,T3) } \\
\text { 3. Meningkatkan kemampuan } \\
\text { SDM melalui pelatihan dan } \\
\text { magang (W3,W5,T3) }\end{array}$ \\
\hline
\end{tabular}




\section{Matriks QSP}

Strategi yang paling tepat untuk pengembangan usaha ikan balita di UD Suhada adalah meningkatkan produksi dan produktivitas usaha ikan balita dalam memanfaatkan permintaan ikan balita yang semakin meningkat (skor 5,734), memanfaatkan teknologi informasi dalam mempromosikan produk ikan balita (skor 5,637), menciptakan variasi produk yang beragam dengan tetap mempertahankan mutu ikan balita (skor 5,605), memperluas jangkauan distribusi dan pemasaran (skor 5,532), bekerjasama dengan pihak peneliti dalam mengembangkan mutu produk ikan balita guna menghadapi persaingan usaha (skor 5,437) dan pengembangan segmentasi usaha dalam menghadapi fluktuasi harga (skor 5,375).

Strategi yang telah dirumuskan pada analisis QSPM tersebut perlu dimplementasikan pada kebijakan usaha. Langkah-langkah tersebut diimplementasikan pada aspek produksi, SDM, pemasaran, dan pengembangan usaha. Uraian implementasi strategi yang dimaksud adalah:

a. Produksi

Alternatif strategik yang dapat dilakukan oleh usaha ikan balita di UD Suhada adalah meningkatkan kapasitas produksi dengan memperluas lahan untuk tempat produksi dan tempat penampungan benih ikan balita dengan memperhatikan permintaan pasar, sehingga fluktuasi harga dapat terjaga. Selain itu memperhatikan pasokan bahan baku di wilayah sekitar yang melimpah dan belum optimal untuk diproduksi menjadi produk ikan balita bermutu, maka perlu diupayakan proses produksi efisien dengan mengadopsi teknologi terkini untuk teknis pengolahan ikan yang baik dan efisien.

b. SDM

Implementasi strategik pada sapek SDM adalah aktif menjalin kerjasama dengan para stekholder terkait dalam menghadapi permasalahan teknis pengolahan ikan balita, yaitu pihak-pihak yang dapat menangani hal tersebut, khususnya dari pemerintah dalam bentuk pendampingan, pembinaan dan subsidi guna penguatan modal usaha. Kerjasama dengan institusi pendidikan, seperti dengan mengadakan magang di tempat usaha ikan balita UD Suhada. Menurut Andriyani, et al (2011). Pengembangan SDM produktif perlu meningkatkan pengetahuan melalui pelatihanpelatihan pembudidayaan ikan dengan memperhatikan teknologi peralatan, bahan baku yang dapat meningkatkan mutu dan modal yang dibutuhkan dalam pembudidayaan ikan dan target pasar.

\section{c. Pemasaran}

Menurut Nainggolan, et al (2010), keunggulan pemasaran adalah harus dapat meningkatkan pelayanan dalam penjualannya, karena dapat menjadi salah satu nilai pembeda dengan pesaing. Pemasaran merupakan suatu hal penting dalam keberlangsungan usaha ikan balita di UD Suhada yang dilihat dari keuntungan. Alternatif strategi yang perlu diimplementasikan terkait pemasaran ikan balita adalah penetrasi pasar dengan penguasaan pasar di seluruh wilayah Jabodetabek dan Jawa Barat. Selain itu memodifikasi produk di wilayah pasar dengan menambah saluran distribusi, serta memperhatikan hal teknologi informasi yang cukup pesat perkembangannya saat ini. Dengan berkembangnya teknologi informasi maka akan membantu pemasaran produk ikan balita di UD Suhada, tidak hanya bertansaksi langsung kepada konsumen atau distributor, melainkan memanfaatkan jejaring sosial di internet dalam memasarkan produk ikan balita di UD Suhada.

Dengan perkembangan dan perluasan pasar, konsumen yang selama ini tidak terakomodasi akibat keterbatasan informasi dan jarak dapat dilayani. Strategi ini diyakini akan bermanfaat untuk meningkatkan penjualan atau pendapatan perusahaan (Suhendar, et al, 2010).

d. Pengembangan usaha

Pengembangan usaha ikan balita di UD Suhada merupakan salah satu upaya mendukung program peningkatan produksi ikan balita. Dalam hal ini, implementasi alternatif strategi adalah pengembangan lahan untuk operasional dan mencari segmentasi usaha sesuai permintaan dan potensi pasar, terutama menjaga kestabilan dalam menghadapi fluktuasi harga.

\section{KESIMPULAN}

a. Kajian kelayakan investasi agribisnis ikan balita di UD Suhada dilihat dari aspek finansial menguntungkan dan layak dilaksanakan. Hal ini ditunjukkan dengan tingkat suku bunga 14\% diperoleh nilai NPV Rp1.105.005. 110, nilai Net B/C Ratio 4,85, nilai IRR $38,95 \%$ lebih besar dari tingkat suku bunga, nilai PBP 3,58 tahun atau nilai ini lebih pendek dari jangka waktu umur ekonomis proyek investasi. Berdasarkan analisis perhitungan BEP diketahui bahwa titik impas untuk usaha pengolahan ikan balita di UD Suhada pada penjualan Rp1.522.035.876 atau dapat juga dikatakan bahwa diperlukan penjualan 32.725 $\mathrm{kg}$ ikan balita segar untuk mendapatkan kondisi seimbang antara biaya dengan keuntungan.

b. Hasil identifikasi faktor internal terdapat delapan kekuatan dan delapan kelemahan, sementara pada faktor lingkungan eksternal terdapat enam peluang dan lima ancaman. Perpaduan nilai IFE dan EFE dalam matriks IE menunjukkan posisi usaha ikan balita di UD Suhada terletak pada sel V (lima), yaitu sel 
pertumbuhan. Strategi yang harus dilakukan adalah penetrasi pasar dan diversifikasi produk.

c. Hasil analisis SWOT dan QSPM yang dapat diimplementasikan pada usaha ikan balita di UD Suhada adalah pada proses produksi yang efisien dengan mengadopsi teknologi terkini untuk teknis pengolahan ikan yang baik dan efisien; kerjasama dengan institusi pendidikan dalam hal proses produksi; penetrasi pasar dengan penguasaan pasar di seluruh wilayah yang lama dan membuka pasar yang baru serta melakukan modifikasi produk di wilayah pasar yang lama dan baru dengan menambah saluran distribusi.

\section{DAFTAR PUSTAKA}

Amri, K dan Khairuman. 2007. Ikan Balita: Peluang Bisnis dan Teknik Produksi Massal. PT. Gramedia Pustaka Utama, Jakarta.

Andriyan, R., M. Hubeis dan A. Munandar. 2011. Kelayakan dan Strategi Pengembangan Usaha Kelompok Pembudidauaan Ikan Melalui Program Replika Skim Modal Kerja di Kelompok Tani Ikan Mekar Jaya Lido, Bogor. Manajemen IKM, 6(1): 9-19.

David, F.R. 2004. Konsep Manajemen Strategis. PT. Prenhallindo, Jakarta.

Dinas Peternakan, Perikanan dan Kelautan Kabupaten Cianjur. 2012. Laporan: Produksi Benih Ikan. Unit Pembenihan Rakyat Kabupaten Cianjur, Cianjur.
Flona Serial. 2007. Menambang Uang dari Kolam Ikan. Majalah Flona, Jakarta.

Husnan dan Suwarsono. 2000. Studi Kelayakan Proyek. UPP, Yogyakarta.

Kusumawardani, IS., I. Gumila dan I. Rostini. 2012. Analisis Surplus Konsumen dan Surplus Produsen Ikan Segar di Kota Bandung. Jurnal Perikanan dan Kelautan, 3(4): 141-150.

Latifah, E., A. Suryani dan H. Hardjomidjojo. 2009. Analisis Kelayakan Pembiayaan Pengembangan Usaha Mebel Kayu Pada Bank Syariah (Studi Kasus : PT. "X" di Bekasi). Jurnal MPI, 4(1): 57-74.

Nainggolan, T.Y., K. Sumantadinata dan A. Suryani. 2010. Strategi Pengembangan Usaha "Nila Puff" dalam Meningkatkan Pendapatan IKM Pengolahan Hasil Perikanan pada CV."X" di Cibinong, Bogor. Manajemen IKM, 5(2): 132-144.

Saragih, B. 2010. Agribisnis : Paradigma Baru Pembangunan Ekonomi Berbasis Pertanian. PT. Penerbit IPB Press, Bogor.

Septiara, I., I. Maulina dan I.D. Buwono. 2012. Analisis Pemasaran Ikan Mas Koki (Carassius Auratus) di Kelompok Pembudidaya Ikan Kelapa Ciung Kecamatan Cimalaka Kabupaten Sumedang. Jurnal Perikanan dan Kelautan, 3(3): 69-73.

Suhendar, U., Soewarno T.S dan N.S. Palupi. 2010. Kajian Strategi Pemasaran Ikan Asap (Smoked Fish) di UKM Petikan Cita Halus Citayam, Bogor. Manajemen IKM, 5 (2): 145-156. 